\title{
Determination and changes of free amino acids in royal jelly during storage
}

\author{
Emanuele Boselli ${ }^{\mathrm{a} *}$, Maria Fiorenza CABONI ${ }^{\mathrm{b}}$, Anna Gloria SABATINI ${ }^{\mathrm{c}}$, \\ Gian Luigi MARCAZZAN ${ }^{c}$, Giovanni LERCKER ${ }^{\mathrm{d}}$

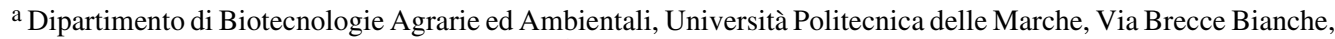 \\ 60131 Ancona, Italy \\ ${ }^{b}$ Dipartimento di Scienze e Tecnologie Agroalimentari, Ambientali e Microbiologiche, Università del Molise, \\ Via De Sanctis, 86100 Campobasso, Italy \\ ${ }^{c}$ Istituto Nazionale di Apicoltura, Via di Saliceto 80, 40128 Bologna, Italy \\ ${ }^{\mathrm{d}}$ Dipartimento di Scienze degli Alimenti, Università di Bologna, Viale G. Fanin, 40, 40127 Bologna, Italy
}

(Received 15 April 2002; revised 25 July 2002; accepted 23 August 2002)

\begin{abstract}
Free amino acids (FAAs) in royal jelly (RJ) were determined and their identification was confirmed with mass spectrometric detection (GC-MS). The presence of D-aminoacids was evaluated using GC with a chiral column. The total FAA content was $7.3 \mathrm{mg} / \mathrm{g}$ RJ on average; the major FAAs were proline, lysine, glutamate, $\beta$-alanine, phenylalanine, aspartate and serine. The concentration of FAAs of the D-series was below the detection limit of the method $(0.1 \mathrm{mg} / \mathrm{g} \mathrm{RJ})$ in all the samples. The FAA fraction was monitored in RJ frozen immediately after sample collection (control) and in aliquots of the same sample stored at two different temperatures (room temperature and $\left.4{ }^{\circ} \mathrm{C}\right)$ for different time intervals $(3,6$ and 10 months). The FAA content was constant throughout storage at $4{ }^{\circ} \mathrm{C}$. However, at room temperature, proline and lysine increased after three months to 6.8 and $3 \mathrm{mg} / \mathrm{g}$, respectively and then decreased after 6 and 10 months to 3 and $1 \mathrm{mg} / \mathrm{g}$.
\end{abstract}

royal jelly / free amino acid / storage condition / gas chromatography-mass spectrometry / chiral separation

\section{INTRODUCTION}

The secretion of the hypopharyngeal or brood food glands in the head of young worker honey bees was termed gelée royale (royal jelly, RJ) by Huber in 1792 (Crane, 1990). Young worker honey bees (called nurses) use $\mathrm{RJ}$ to feed young larvae of workers and drones for less than three days (Chen and Chen, 1995). In contrast, the queen bee is fed with RJ throughout her life and the cast differentiation between queen and worker bees is related strictly to differences in the feeding of the larvae. The physiological effects of RJ in humans is still not understood. However, RJ has been recognized in the world market as a dietary supplement and is used in cosmetics for its alleged tonic and bio-stimulating effects.

Commercially, $\mathrm{RJ}$ is the food of queen bee larvae harvested when the larvae are four to five days old (Piana, 1996). Quality control of RJ involves the study of its composition and the changes in the components during both commercial and domestic storage. The composition of freshly harvested and commercial

\footnotetext{
* Correspondence and reprints

E-mail: eboselli@agr.unian.it
} 
RJ has been studied extensively (Crane, 1990; Howe et al., 1985; Palma, 1992).

Modifications that affect the protein and amino acid fractions should play an important role in assessing the commercial quality of RJ during the shelf life of the product. The browning reaction in RJ stored at room temperature is appreciable after only a few weeks (Chen and Chen, 1996). Modifications of the watersoluble protein (WSP) fraction (Chen and Chen, 1995) and the enzymatic activity (Baggio and Dainese, 1998). have been studied already. Free amino acids (FAAs) are involved in the browning process that occurs during the commercial storage of food. The GC determination of FAAs has been described in bee-hive products other than RJ, such as honey (Pirini et al., 1992), propolis (Gabrys et al., 1986) and pollen (Serra Bonvehì, 1991). However, the quantitative determination of FAAs in RJ and their changes during storage have received little research attention due to the laborious sample preparation. RJ is characterized by a complex composition: moisture $(60-70 \%)$, crude protein $(12-15 \%)$, lipids (3$6 \%$, most of which are free fatty acids) (Lercker et al., 1981) and sugars (10-16\%) (Crane, 1990; Chen and Chen, 1995). In previous work (Serra Bonvehì, 1990), FAAs were purified using a cation exchange resin and derivatization prior to the gas chromatographic determination. Amino acids are purified and determined also using cation-exchange chromatography with post-column derivatization and spectrophotometric detection (EN 12742, 1999), reversed-phase high performance liquid chromatography with pre-column derivatization and spectrophotometric detection (Woo, 2001) and capillary electrophoresis (Ummadi and Weimer, 2002). However, an extremely selective technique, such as gas chromatography-mass spectrometry (GCMS) is a powerful tool to confirm unambiguously the identification of FAAs.

The aim of this work was to quantitatively determine the free amino acids in RJ by means of capillary gas chromatography performed with a chiral (chirasil-L-val) stationary phase. The use of a chiral stationary phase allows for the quantification of D-AA in RJ, which, to our knowledge, has never been done. The modifications of the FAA fraction were monitored in RJ immediately freezed after the sample collection (control) and in the same sample stored at two different temperatures (room temperature and $4{ }^{\circ} \mathrm{C}$ ) for different time intervals (3, 6 and 10 months).

\section{MATERIALS AND METHODS}

\subsection{Reagents and standards}

The solvents (ethyl alcohol and dichloromethane) were of analytical grade. The pure FAA standards (L- and D-isomers) were obtained by SigmaAldrich (St. Louis, MO, USA. Standards of free fatty acids were sebacic acid (Seb, decanedioic acid), and 10-hydroxydecanoic acid (10-OH). Each substance was diluted in $\mathrm{HCl} 0.1 \mathrm{~N}(2 \mathrm{mg} / \mathrm{mL}$ as the final concentration). For identification, $250 \mu \mathrm{L}$ of the solution was derivatized according to the procedure reported below. The residue was dissolved in $1 \mathrm{~mL}$ dichloromethane and injected in GC $(1 \mu \mathrm{L})$. The strong acidic exchange resin used for the cleanup procedure was from Sigma-Aldrich (Dowex 50WX8, 100-200 mesh). Reagents for derivatization were from Carlo Erba (Milan, Italy) (ammonia $28 \%$ solution and iso-butanol) and Fluka (Buchs, Switzerland) (heptafluorobutyryl anhydride, HFBA $>99 \%$ purity).

\subsection{Samples}

Royal jelly ( $50 \mathrm{~g})$ was harvested by 10 different beekeepers in the region of Emilia Romagna (Italy) and immediately stored at $4{ }^{\circ} \mathrm{C}$ until preparation of the samples in the laboratory $(2 \mathrm{~h})$. After accurate homogenization, RJ was divided in 14 aliquots $(3 \mathrm{~g}$ for each sample). Each aliquot was placed in a glass vial and closed. Two vials were immediately stored at $-18{ }^{\circ} \mathrm{C}$ and represented the control. The remaining 12 samples were divided into two groups. The first group was stored at room temperature for 3, 6 and 10 months in two replications. The second group of samples were stored at $4{ }^{\circ} \mathrm{C}$ for the same time intervals. When the programmed storage time for each sample was reached, the sample vial was frozen $\left(-18{ }^{\circ} \mathrm{C}\right)$. Thus, all the 14 samples were analyzed in a single run at the end of the experimentation.

\subsection{Extraction and ion exchange cleanup of FAAs}

RJ (1 g) was mixed with a solution of ethanol (95\%) and $\mathrm{HCl} 1 \mathrm{~N}(70: 25, \mathrm{v} / \mathrm{v})$ according to (Bertacco et al., 1992). An internal standard $(100 \mu \mathrm{L}$ of a $10 \mathrm{mg} / \mathrm{mL}$ solution of homoserine in $\mathrm{HCl} 1 \mathrm{~N}$ ) was added. The slurry was heated to the 
boiling point and immediately cooled for $2 \mathrm{~h}$ at room temperature. The supernatant $(10 \mathrm{~mL})$ was transferred to a glass vial with screw cap and centrifuged at $2000 \mathrm{~g}$ for $5 \mathrm{~min}$. The clear acid $(\mathrm{pH}$ $<2.5$ ) solution $(1 \mathrm{~mL})$ was purified through elution on a strong cationic exchange resin column following the procedure reported elsewhere (Pirini, 1992). The column (10 mm i.d.) was prepared with $1.1 \mathrm{~g}$ of resin previously washed with hydrochloric acid $(1 \mathrm{~N}, 10 \mathrm{~mL})$ and subsequently washed with distilled water until the washings were neutral (about $30 \mathrm{~mL}$ ). The elution flow was 1 drop/s. Sugars and part of the free fatty acids were eliminated by elution with $6 \mathrm{~mL} \mathrm{HCl} \mathrm{N/100.} \mathrm{Amino}$ acids were eluted with $30 \mathrm{~mL}$ aqueous ammonia $(2 \mathrm{~N})$. The FAA fraction was transferred into a flask and the solvent was dried with a rotary vacuum evaporator at $40^{\circ} \mathrm{C}$.

\subsection{Derivatization}

The derivatization of FAAs was performed according to a previous work (Bertacco et al., 1992). The dried FAA extract was immediately rinsed twice with $500 \mu \mathrm{L}$ of isobutanol/3N HCl during sonication of the flask. The reaction mixture was introduced into a Pyrex ${ }^{\circledR}$ test tube and closed with a screw cap covered by a teflon septum. After heating the tube in an oven at $110^{\circ} \mathrm{C}$ for $30 \mathrm{~min}$, the sample was cooled and dried with a gentle nitrogen flow. Then, the sample was dried a second time after addition of $150 \mu \mathrm{L}$ of dichloromethane to eliminate the residual moisture. Dichloromethane $(30 \mu \mathrm{L})$ and $150 \mu \mathrm{L}$ heptafluorobutyryl anhydride (HFBA) were added to the dry residue in the tube. The tube was closed a second time and heated at $125{ }^{\circ} \mathrm{C}$ for $20 \mathrm{~min}$. Finally, $50 \mu \mathrm{L}$ dichloromethane was added after evaporation of the solvent with a nitrogen flow. The derivatized sample was then analyzed by GC.

\subsection{GC-FID with a chiral stationary phase}

The quantitative determination and separation of FAA enantiomers was performed with a gas chromatograph (Fractovap 4160, Carlo Erba Instruments, Rodano, Italy) equipped with a split-splitless injector and a flame ionization detector (FID). A fused silica capillary column $(25 \mathrm{~m} \times 0,25 \mathrm{~mm}$ id $)$ coated with a film of Chirasil-L-Val (N-propionylL-valine tert-butylamide polysiloxane; $0.12 \mu \mathrm{m}$ film thickness) from Chrompack (Middelburg, The Netherlands) was used. The samples $(1 \mu \mathrm{L})$ were injected with the split mode. The oven temperature was programmed from $75^{\circ} \mathrm{C}$ to $200{ }^{\circ} \mathrm{C}$ at a rate of $8^{\circ} \mathrm{C} / \mathrm{min}$. The final temperature was maintained for $10 \mathrm{~min}$; the injector and detector temperatures were set at $200{ }^{\circ} \mathrm{C}$. Helium was used as the carrier gas at a flow of $1 \mathrm{~mL} / \mathrm{min}$ (measured at $75^{\circ} \mathrm{C}$ ); the split ratio was $1: 20$.

\subsection{GC-MS with a non-polar stationary phase}

The identification of FAA was confirmed using mass spectrometric analysis. The GC-MS comprised a 3400 gas chromatograph (Varian, Palo Alto, CA, USA) and an ion trap system (ITS 40) from Finnigan (Manchester, UK). The fused silica capillary column $(30 \mathrm{~m} \times 0.25 \mathrm{~mm}$ id $)$ was a $\mathrm{ZB}-5$ Phenomenex (Torrance, CA, USA) coated with 5\% phenyl-polysiloxane $(0.25 \mu \mathrm{m}$ film thickness $)$. The carrier gas flow (helium) was $1.4 \mathrm{~mL} / \mathrm{min}$ and the split ratio was 1:20. The temperature of the injector was set at $290^{\circ} \mathrm{C}$ and the transfer line was heated at $300{ }^{\circ} \mathrm{C}$. The initial oven temperature $\left(75^{\circ} \mathrm{C}\right)$ was maintained for $2 \mathrm{~min}$ and then raised to $250{ }^{\circ} \mathrm{C}$ at a rate of $5^{\circ} \mathrm{C} / \mathrm{min}$. The mass detector was used in the electronic impact mode $(70 \mathrm{eV})$ and the scan rate was $1 \mathrm{scan} / \mathrm{s}$. A solvent delay of $180 \mathrm{~s}$ was used before acquisition. Before analysis, the samples were diluted 1:20 with respect to the GC-FID configuration.

\subsection{Repeatability, recovery and GC-FID response factor}

The recovery of the derivatization step was evaluated together with the GC response by performing the derivatization (in three replications) and GC-FID determination of a standard mixture of FAAs. Secondly, the recovery of the clean-up procedure was evaluated by adding a known amount of the amino acid standard solution to the extraction mixture. The clean-up, derivatization and GC analysis were then performed as described above in three replications.

\section{RESULTS AND DISCUSSION}

\subsection{Clean-up of FAAs from royal jelly}

As a preliminary step, the precipitation of proteins was accomplished according to Bertacco et al. (1992). Successively, the ion exchange clean-up and the derivatization method described by Pirini et al. (1992) was adapted to the case of RJ. The response factors for the derivatization of the FAAs were calculated and are reported in Table I. The relative standard deviation ( $\mathrm{rsd} \%$ ) of the response factor was acceptable for the major FAAs and 
Table I. Response factors of the major Free amino acids (FAAs). The standard solution of FAAs was derivatized and analyzed in three replications $(\mathrm{n}=$ 3). Data are normalized with respect to the internal standard (homoserine). rsd, relative standard deviation.

\begin{tabular}{lcc}
\hline amino acid & $\begin{array}{c}\text { average } \\
\text { response factor }\end{array}$ & $\begin{array}{c}\mathrm{rsd} \% \\
(\mathrm{n}=3)\end{array}$ \\
\hline Alanine (Ala) & 0.82 & 30 \\
Aspartic acid (Asp) & 1.10 & 3 \\
Glutamic acid (Glu) & 1.06 & 3 \\
Glycine (Gly) & 0.97 & 11 \\
Homoserine (Hom) & 1.00 & --- \\
Isoleucine (Ile) & 1.00 & 8 \\
Lysine (Lys) & 1.07 & 8 \\
Hydroxyproline (OH-Pro) & 1.06 & 4 \\
Ornitine (Orn) & 1.02 & 5 \\
Phenylalanine (Phe) & 1.05 & 3 \\
Proline (Pro) & 1.04 & 0.7 \\
Serine (Ser) & 0.85 & 6 \\
Threonine (Thr) & 1.04 & 5 \\
Tyrosine (Tyr) & 0.98 & 47 \\
Valine (Val) & 0.92 & \\
\hline
\end{tabular}

ranged from 0.7 to 8 . Alanine, valine and glycine showed a rsd higher than $11 \%$ due to the volatility of their derivatives. These compounds eluted very early in gas chromatography and their rsd decreased with the increasing GC retention time. The recovery efficiency of the clean-up procedure was also evaluated by performing the complete analysis on three replications of the standard mixture. In all cases, the average efficiency of recovery was higher than $78 \%$ with respect to the internal standard (homoserine), except for methionine (46\%).

Histidine could not be analyzed due to the uncomplete acylation under these conditions (MacKenzie and Tenaschuk, 1974). Aspartic acid and asparagine, as well as glutamic acid and glutamine, form only one peak (reported as Asx and Glx, respectively) because identical esters are generated from both acids and amides with HFBA (Pirini et al., 1992).

\subsection{Gas chromatography (GC) and mass fragmentation of the derivatized free amino acids}

Although performing ion exchange chromatography, the eluate was rich in short chain free fatty acids, which represented $80 \%$ of the lipid fraction of RJ. The efficiency of ion exchange chromatography was evaluated by using a standard mixture of sebacic acid and homoserine in a concentration ratio of $5: 1$, which was approximately the ratio occurring in our sample. The mixture was treated as a real sample and purified by ion exchange chromatography: $82 \%$ of sebacic acid was eliminated with respect to homoserine. This result showed that particular care should be used in the identification of FAAs. To obtain an unambiguous determination of FAAs, the chromatograms recorded with chiral stationary phase were compared with those resulting from GC-Mass Spectrometry (GC-MS). In GC-MS, the elution order of the FAA derivatives was different, due to the different phase selectivity; the elution of lysine and homoserine was anticipated with respect to proline, which was the main FAA. However, serine and $\beta$-alanine were eluted later than with the chiral phase. Two pairs of substances coeluted using the chiral phase: tyrosine coeluted with a fatty acid, whereas $\beta$-alanine coeluted with isoleucine. The non polar GC phase allowed the separation of both the critical pairs. Consequently, the tyrosine content was found to be less than $100 \mu \mathrm{g} / \mathrm{g}$ of RJ.

The mass fragmentation of derivatized alanine and $\beta$-alanine is reported in Figure 1 and that of derivatized aspartate and proline in Figure 2. The molecular ion was present in all the reported fragmentations. Characteristic fragments of heptafluorobutyryl derivatives are those at $\mathrm{m} / \mathrm{z} 69\left(\mathrm{CF}_{3}\right), 119\left(\mathrm{C}_{2} \mathrm{~F}_{5}\right)$ and 169 $\left(\mathrm{C}_{3} \mathrm{~F}_{7}\right)$. However, the most abundant ions were consistent with the presence of a secondary amine (a tertiary amine in the case of derivatized proline) and a carboxylic ester moiety. Thus, the loss of the isobutyl group (with or without hydrogen migration) gave origin to the ions at M-56 and M-55, respectively.

The fragments at M-101 and M-102 were abundant and arose from the loss of $\mathrm{C}_{5} \mathrm{H}_{9} \mathrm{O}$ and $\mathrm{C}_{5} \mathrm{H}_{10} \mathrm{O}$, respectively. The ion $\mathrm{M}-101$ was in fact the base peak of the proline derivative. 

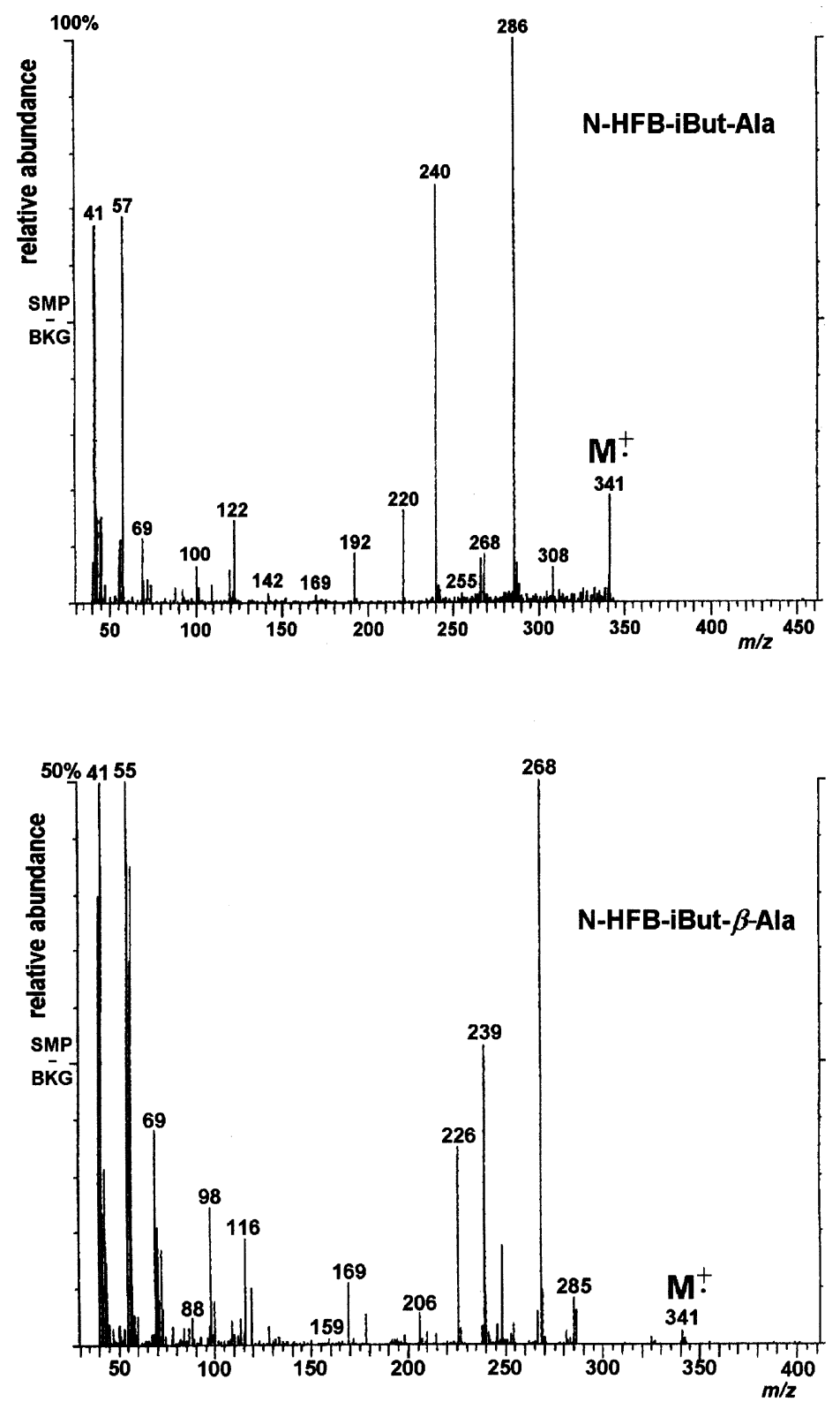

Figure 1. Mass fragmentation of derivatized alanine and $\beta$-alanine; SMP-BKG, the background (BKG) mass peaks were subtracted from the sample (SMP) mass peaks; $\mathrm{M}^{+}$, molecular peak; $\mathrm{m} / \mathrm{z}$, mass-to-charge ratio.

The base peak of $\beta$-alanine at $\mathrm{m} / \mathrm{z}=268$ derived from the loss of $\mathrm{C}_{4} \mathrm{H}_{9} \mathrm{O}$, the isobutoxy radical, which was also present in alanine as a minor fragment. The spectrum of $\beta$-alanine also contained the fragment at $\mathrm{m} / \mathrm{z}=226$, due to the fission of $\mathrm{C}_{6} \mathrm{H}_{11} \mathrm{O}_{2}$; the latter was absent in the spectrum of alanine. The two isobutylesters of aspartate produced a peculiar fragmentation pattern: the base peak at $\mathrm{m} / \mathrm{z}=$ 284 was due to the contemporary loss of 

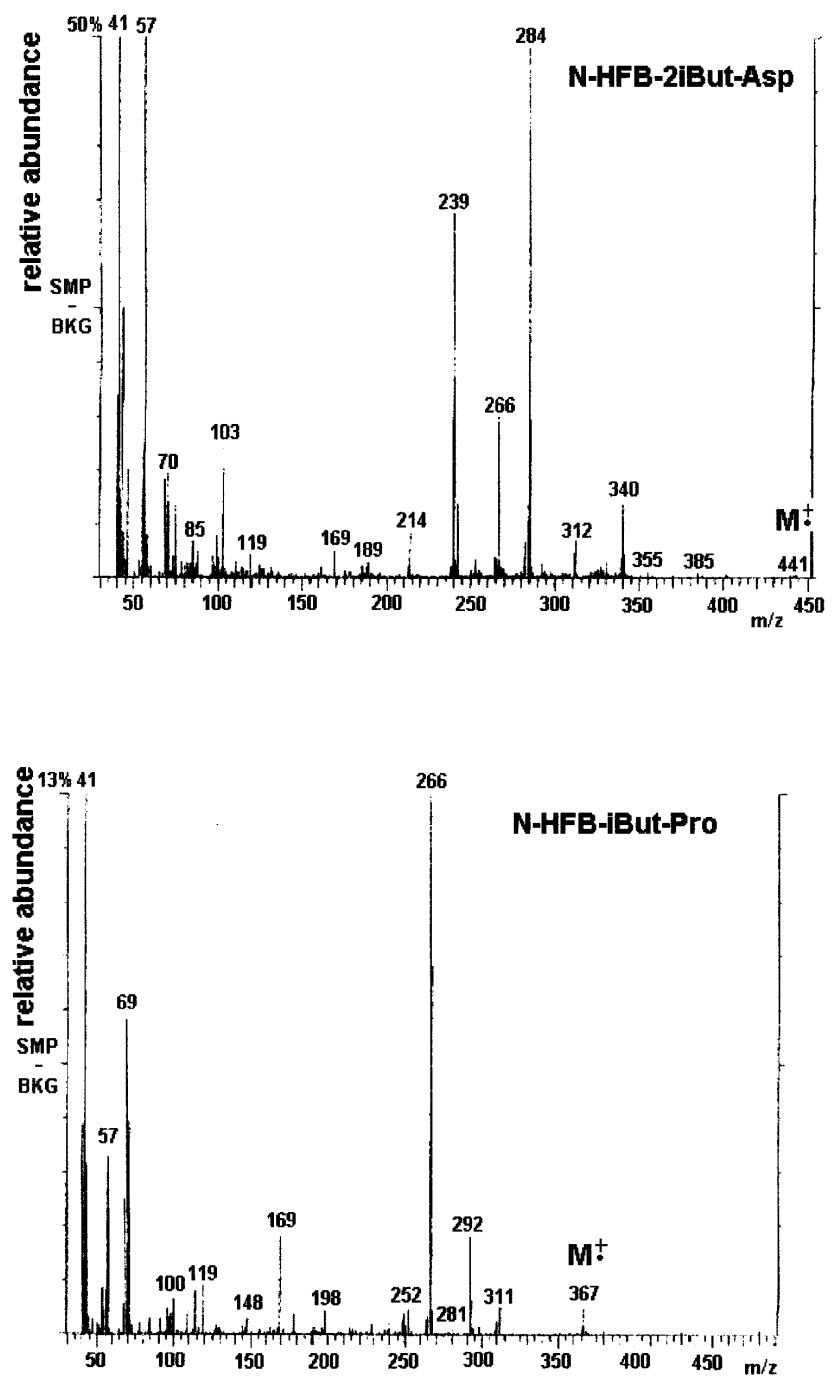

Figure 2. Mass fragmentation of derivatized aspartate and proline; SMP-BKG, the background (BKG) mass peaks were subtracted from the sample (SMP) mass peaks; $\mathrm{M}^{+\cdot}$, molecular peak; $\mathrm{m} / \mathrm{z}$, mass-to-charge ratio.

$\mathrm{C}_{5} \mathrm{H}_{9} \mathrm{O}_{2}$ and $\mathrm{C}_{4} \mathrm{H}_{8}$; moreover, the loss of both the $\mathrm{C}_{5} \mathrm{H}_{9} \mathrm{O}_{2}$ radicals yielded the fragment at $\mathrm{m} / \mathrm{z} 239$ [M-(101+101)]. The ion at $\mathrm{m} / \mathrm{z}=266$ should have arisen from the contemporary elimination of $\mathrm{C}_{5} \mathrm{H}_{9} \mathrm{O}_{2}$ and $\mathrm{C}_{4} \mathrm{H}_{10} \mathrm{O}$ (isobutylalcohol), whereas the fragment at $\mathrm{m} / \mathrm{z}=312$ should have been formed by contemporary elimination of $\mathrm{C}_{4} \mathrm{H}_{8}$ and $\mathrm{C}_{4} \mathrm{H}_{9} \mathrm{O}$.

\subsection{Composition of FAA of royal jelly}

Concentrations of FAAs found in RJ samples and their internal percentage are reported in Table II. The FAA content ranged from 5 to $15 \mathrm{mg}$ per $\mathrm{g}$ of RJ. These data are in agreement with previous literature, as well as the internal percentage. Proline appeared to be the major FAA contained in RJ unlike other food of animal origin. The high concentration of free proline in bee haemolymph has been already stated (Lue and Dixon, 1967) and determined quantitatively (Crailsheim and Leonhard, 1997; Leonhard and Crailsheim, 1999). Proline is not an essential amino acid for insects, but its relationship with energetic metabolism 
Table II. Free amino acids determined in samples of royal jelly (RJ); r.t., storage at room temperature. The average of 14 samples $(n=14)$ is reported below.

\begin{tabular}{|c|c|c|c|c|c|c|c|c|c|}
\hline \multicolumn{10}{|c|}{ Average FAA concentration $(\mathrm{mg} / \mathrm{g} \mathrm{RJ}) \pm \mathrm{sd}(\mathrm{n}=2)^{(1)}$} \\
\hline \multicolumn{2}{|c|}{ treatment } & \multicolumn{8}{|c|}{ Free amino acids } \\
\hline $\begin{array}{l}\text { storage time } \\
\text { (months) }\end{array}$ & $\begin{array}{c}\text { storage } \\
\text { temperature }\left({ }^{\circ} \mathrm{C}\right)\end{array}$ & $\beta$-Ala & Pro & Ser & Asx ${ }^{(2)}$ & Phe & Glx (2) & Lys & $\begin{array}{l}\text { sum of } \\
\text { FAAs }\end{array}$ \\
\hline 10 & -18 & $0.39 \pm 0.02$ & $3.9 \pm 0.1$ & $0.19 \pm 0.06$ & $0.27 \pm 0.01$ & $0.22 \pm 0.08$ & $0.6 \pm 0.03$ & $1.1 \pm 0.1$ & $6.70 \pm 0.02$ \\
\hline 3 & 4 & $0.39 \pm 0.03$ & $3.7 \pm 1.0$ & $0.2 \pm 0.03$ & $0.38 \pm 0.03$ & $0.41 \pm 0.2$ & $0.59 \pm 0.04$ & $1.3 \pm 0.4$ & $6.97 \pm 0.4$ \\
\hline 3 & r.t. & $0.58 \pm 0.1$ & $6.8 \pm 2.4$ & $0.10 \pm 0.03$ & $0.48 \pm 0.1$ & $0.23 \pm 0.2$ & $1.0 \pm 0.3$ & $3.0 \pm 1.1$ & $11.8 \pm 3.8$ \\
\hline 6 & 4 & $0.27 \pm 0.1$ & $3.9 \pm 0.2$ & $0.14 \pm 0.03$ & $0.26 \pm 0.1$ & $0.38 \pm 0.2$ & $0.51 \pm 0.2$ & $1.3 \pm 0.6$ & $6.9 \pm 0.06$ \\
\hline 6 & r.t. & $0.35 \pm 0.1$ & $2.5 \pm 0.1$ & $0.16 \pm 0.1$ & $0.34 \pm 0.1$ & $0.43 \pm 0.2$ & $0.61 \pm 0.2$ & $1.1 \pm 0.3$ & $5.5 \pm 0.5$ \\
\hline 10 & 4 & $0.30 \pm 0.1$ & $3.7 \pm 0.7$ & $0.14 \pm 0.06$ & $0.33 \pm 0.08$ & $0.43 \pm 0.4$ & $0.78 \pm 0.2$ & $1.0 \pm 0.04$ & $6.8 \pm 0.5$ \\
\hline \multirow[t]{4}{*}{10} & r.t. & $0.34 \pm 0.03$ & $3.0 \pm 0.7$ & $0.15 \pm 0.08$ & $0.36 \pm 0.1$ & $0.42 \pm 0.4$ & $0.63 \pm 0.1$ & $1.1 \pm 0.1$ & $6.0 \pm 0.01$ \\
\hline & average $(n=14)$ & 0.4 & 4.0 & 0.2 & 0.4 & 0.4 & 0.7 & 1.4 & 7.3 \\
\hline & $\operatorname{rsd} \%$ & 32 & 39 & 41 & 28 & 60 & 30 & 54 & 32 \\
\hline & internal percent & 5.2 & 54.2 & 2.2 & 4.8 & 5.0 & 9.4 & 19.6 & 100.0 \\
\hline
\end{tabular}

(1) n, number of replications.

(2) Asx, sum of aspartic acid and asparagine; Glx, sum of glutamic acid and glutamine.

during flight has been studied (Micheu et al., 2000). Our data show that proline is transferred from the worker's haemolymph into RJ as food for the young bee larvae. A non proteic amino acid was found in RJ, namely $\beta$-alanine. The GC-FID determination was not sufficient to identify $\beta$-alanine, because this amino acid coeluted together with isoleucine when using the chiral stationary phase. Thus, the identification of the peak was performed correctly using a non-polar column (which has a different selectivity) fitted in GC-MS; the presence of isoleucine in the samples was under the detection limit $(100 \mu \mathrm{g} / \mathrm{g}$ of RJ). $\beta$-alanine has been found in the extracellular fluids of bee, particularly in the interstitial fluid of the retina (Cardinaud et al., 1994). Phenylalanine and lysine were the only essential amino acids found in the samples. In contrast, the amount of $\mathrm{D}$-aminoacids was lower than the detection limit, evidence that the microbiological contamination of the sample and the bacterial enzymatic activity were negligible.

\subsection{Changes of the FAA content during storage at different temperature and time conditions}

The changes of total FAA content during storage at $4{ }^{\circ} \mathrm{C}$ and at room temperature are reported in Table II. The quantitative data showed that the two different storage temperatures affected the FAA content to a significant extent.

The FAA content was constant throughout storage at the usual refrigerator temperature. Since the enzymatic activity and the Maillard reaction (non enzymatic browning process) are the major degradation processes occurring during the conservation of RJ, the results showed that both these reactions were slowed under these conditions. In addition, a selective modification of one or more FAAs was not registered in the samples stored at $4{ }^{\circ} \mathrm{C}$.

However, the behavior during storage at room temperature was different. The FAA concentration increased during the first 3 months. After three months, the degradation of FAAs became faster than the formation (by synthetic pathways or protein hydrolysis); finally the concentration value became slightly lower than the control. It should be mentioned that all the samples were kept in the dark during the experimentation, thus photoxidation was negligible.

The product stored at room temperature exhibited a different selectivity in the degradation of the FAAs. For proline and lysine a typical concentration peak was registered (concentration as a function of storage time). This trend was reported also for $\beta$-alanine, but to a lesser extent. On the other hand, serine 
was immediately degraded during the first three months. Aspartate and glutamate were not affected: their content was stable over ten months. The phenylalanine content was very variable with respect to the storage interval at room temperature.

The extent of the Maillard reaction has been already measured by previous authors with spectrophotometric methods (Palma, 1992; Chen and Chen, 1996) and affects the degradation of FAAs. Since our work showed that FAAs are not end products during the conservation of $\mathrm{RJ}$, these alone are not a suitable parameter to predict the quality conditions of this product. In fact a low concentration of FAAs could be related to the initial stage of conservation (freshly harvested RJ) or to the further degradation due to the Maillard reaction. For these reasons, a quality parameter of freshness for RJ should be the determination of the stable products of the Maillard reaction (Marconi et al., 2002).

\section{ACKNOWLEDGMENTS}

This research project was part of the Progetto Finalizzato AMA (Ape, Miele, Ambiente) supported by the Italian 'Ministero delle Politiche Agrarie e Forestali' (Contributo No. 135).

Résumé - Détermination et modifications des acides aminés libres de la gelée royale au cours du stockage. D'un point de vue commercial, la gelée royale (GR) est la nourriture destinée aux larves des futures reines d'abeilles âgées de quatre à cinq jours. Récemment la GR a acquis une place dans le commerce mondial comme supplément diététique et dans les cosmétiques pour ses effets prétendus toniques et bio-stimulants. Le contrôle de la qualité de la GR est donc un sujet important qui reste mésestimé. L'évaluation de la qualité de la GR implique l'étude de sa composition et des changements des composants au cours du stockage commercial et domestique afin de définir des marqueurs de qualité. Les aspects de la détermination des acides aminés libres (AAL) dans la GR et les modifications des AAL au cours de la durée de conservation avant la vente sont discutés dans cette étude. Le nettoyage des AAL est l'étape préliminaire à la détermination et a été faite par les techniques de chromatographie. Le but était de réduire la présence de substances qui interfèrent, telles que les sucres et les acides organiques à chaîne courte, qui sont d'autres composants naturels de la GR. Les principaux AAL des séries L sont la proline $(2,4-5,4 \mathrm{mg} / \mathrm{g} \mathrm{GR})$, la lysine $(0,6-2,2)$, le glutamate
$(0,5-0,9)$, la $\beta$-alanine $(0,3-0,5)$, la phénylalanine $(0,2-0,6), 1$ 'aspartate $(0,2-0,5)$ et la sérine $(0,1-0,3)$ (domaine de concentration moyenne). La concentration des AAL des séries-D était inférieure à la limite de détection de la méthode $(0,1 \mathrm{mg} / \mathrm{g} \mathrm{GR})$ dans tous les échantillons, ce qui montre que l'activité microbienne était insignifiante. Les modifications de la fraction AAL ont été analysées dans la GR immédiatement congelée après le prélèvement de l'échantillon (témoin) et dans des fractions du même échantillon conservées à deux températures différentes (température ambiante et à $4{ }^{\circ} \mathrm{C}$ ) durant des périodes de 3, 6 et 10 mois. La teneur en AAL est restée constante durant tout le stockage à $4{ }^{\circ} \mathrm{C}$. Mais à la température ambiante, la proline et la lysine ont d'abord augmenté jusqu'à 6,8 et $3 \mathrm{mg} / \mathrm{g}$, respectivement, durant les trois premiers mois puis ont diminué pour atteindre 2,5 et $1 \mathrm{mg} / \mathrm{g}$ après 6 mois et 3 et $1 \mathrm{mg} / \mathrm{g}$ après 10 mois de stockage (Tab. II). Cette étude confirme que les AAL ne sont pas des produits terminaux formés au cours de l'évolution de la GR mais des produits intermédiaires impliqués dans les réactions qui ont lieu à température ambiante, telles que le processus de brunissement (réaction de Maillard).

gelée royale / acide aminé libre / stockage / contrôle qualité / séparation chirale / chromatographie gazeuse-spectrométrie de masse

Zusammenfassung - Bestimmung und Änderungen der freien Aminosäuren im Königinnenfuttersaft während der Lagerung. Im Handel wird Königinnenfuttersaft (RJ) vertrieben, der als Nahrung für Königinnenlarven im Alter von 4-5 Tagen dient. Auf Grund seiner angeblich stärkenden und bio-stimulierenden Wirkungen eroberte sich RJ in der letzten Zeit im Weltmarkt einen Platz zur diätischen Ergänzung und in der Kosmetik. Deshalb hat die Qualitätskontrolle von RJ eine wichtige und bisher unterschätzte Bedeutung. Zur Erstellung der Richtlinien für die Qualität von RJ ist die Untersuchung seiner Zusammensetzung und der Veränderungen seiner Bestandteile sowohl bei kommerzieller als bei der Aufbewahrung $\mathrm{zu}$ Hause erforderlich, um Qualitätsmerkmale zu bestimmen. Die Bedeutung der Bestimmung der freien Aminosäuren (FAA) im Futtersaft (RJ) und ihre Veränderungen im Zusammenhang mit der kommerziellen Lagerung wird in dieser Studie diskutiert. Die Reinigung der FAAs ist der erste Schritt für ihre Bestimmung und wurde mit chromatographischen Methoden erreicht. Dazu mussten vor allem Substanzen wie Zucker und kurzkettige organische Säuren reduziert werden, die ebenfalls natürliche Komponenten im RJ sind, aber bei der FAA Bestimmung stören. Die häufigsten FAAs der LSerie waren Prolin $(2,4-5,4 \mathrm{mg} / \mathrm{g}$ RJ), Lysin $(0,6-$ $2,2)$, Glutamat $(0,5-0,9), \quad \beta$-Alanin $(0,3-0,5)$, Phenylalanin $(0,2-0,6), \quad$ Asparaginsaures Salz 
$(0,2-0,5)$ und Serin $(0,1-0,3)$ (Bereich mittlerer Konzentration). Die Konzentration der FAAs der DSerie dieser Methode $(0,1 \mathrm{mg} / \mathrm{g} \mathrm{RJ})$ lag in allen Proben unterhalb der Nachweisgrenze, was eine unbedeutende mikrobische Aktivität bedeutet. Die Änderungen der FAA Fraktionen wurden im RJ überwacht, das sofort nach der Gewinnung eingefroren wurde (Kontrolle). Zwei gleiche Mengen vom selben RJ wurden bei unterschiedlichen Temperaturen aufbewahrt (Raumtemperatur und $4{ }^{\circ} \mathrm{C}$ ) und nach unterschiedlichen Zeitabständen (3, 6 und 10 Monate) überprüft. Der FAA Gehalt blieb bei der Lagerung von $4{ }^{\circ} \mathrm{C}$ konstant. Bei Raumtemperatur jedoch nahmen Prolin und Lysin in den ersten 3 Monaten auf 6,8 bzw. $3 \mathrm{mg} / \mathrm{g} \mathrm{zu}$, nahmen aber nach 6 und 10 Monaten auf 3 bzw. $1 \mathrm{mg} / \mathrm{g}$ ab. Diese Untersuchung beweist, dass die FAAs keine Endprodukte während der Entwicklung von RJ sind, sondern Zwischenprodukte, die an Reaktionen beteiligt sind, die bei Raumtemperatur ablaufen, wie z.B. dem Bräunungsprozess.

Königinnenfuttersaft / freie Aminosäuren / Lagerungsbedingungen / Gas ChromatographieMass Spectrographie / chirale Trennung

\section{REFERENCES}

Baggio A., Dainese N. (1998) La qualità della gelatina reale nella conservazione, Ind. Aliment., XXXVII, novembre, pp. 1290-1295.

Bertacco G., Boschelle O., Lercker G. (1992) Gas chromatographic determination of free amino acids in cheese, Milchwissenschaft 47, 348-350.

Cardinaud B., Coles J.A., Perrottet P., Spencer A.J., Osborne M.P., Tsacopoulos M. (1994) The composition of the interstitial fluid in the retina of the honeybee drone: implications for the supply of substrates of energy metabolism from blood to neurons, Proc. R. Soc. London B 257, 9-58.

Chen C., Chen S. (1995) Changes in protein components and storage stability of Royal Jelly under various conditions, Food Chem. 54, 195200.

Chen C., Chen S. (1996) Changes in UV-VIS spectroscopic spectra and quality stability of RJ under various storage conditions, J. Chin. Agric. Chem. Soc. (Zhongguo Nongye Huaxue Huizhi) 34, 257-265.

Crailsheim K., Leonhard B. (1997) Amino acids in honeybee worker haemolymph, Amino Acids 13, 141-153.

Crane E. (1990) Bees and beekeping - Science, practice and world resources, Heinemann Newnes: Oxford, UK.

European Norm 12742 (1999) Fruit and vegetable juices, Determination of the free amino acids content, liquid chromatographic method, European Committee for Standardization (CEN), Bruxelles.
Gabrys J., Konecki J., Krol W., Scheller S., Shani J. (1986) Free amino acids in bee hive product (propolis) as identified and quantified by gasliquid chromatography, Pharmacol. Res. Commun. 18, 513-518.

Howe S.R., Dimick P.S., Benton A.W. (1985) Composition of freshly harvested and commercial royal jelly, J. Apic. Res. 24, 52-61

Leonhard B., Crailsheim K. (1999) Amino acids and osmolarity in honeybee drone haemolymph, Amino Acids 17, 195-205.

Lercker G., Capella P., Conte L.S., Ruini F., Giordani G. (1981) Components of royal jelly: I. Identification of the organic acids, Lipids 12, 912-919.

Lue P.F., Dixon S.E. (1967) Studies in the mode of action of Royal Jelly in Honeybee Development VII. The free amino acids in the haemolymph of developing larvae, Can. J. Zool. 45, 205-214.

MacKenzie S.L., Tenaschuk D. (1974) Gas-liquid chromatography of N-heptafluorobutyryl isobutyl esters of amino acids, J. Chromatogr. 97, 19-24.

Marconi E., Messia C., Panfili G., Caboni M.F. (2002) Furosine: An appropriate marker to assess the royal jelly freshness, J. Agric. Food Chem. 50, 2825-2829.

Micheu S., Crailsheim K., Leonhard B. (2000) Importance of proline and other amino acids during honeybee flight (Apis mellifera carnica Pollmann), Amino Acids 18, 157-175.

Palma M.S. (1992) Composition of freshly harvested Brazilian royal jelly: Identification of carbohydrates from the sugar fraction, J. Apic. Res. 31, 42-44.

Piana L. (1996) Value-added products from beekeeping - Royal jelly, FAO Agric. Serv. Bull. 124, 195-226.

Pirini A., Conte L.S., Francioso O., Lercker G. (1992) Capillary Gas Chromatographic Determination of Free Amino Acids in Honey as a Means Discrimination between Different Botanical Sources, J. High Resol. Chromatogr. 15, 165-170.

Serra Bonvehì J. (1990), Éstudio de la proteina y aminoacidos libres de la jalea real, An. Bromatol. XLII, 353-365.

Serra Bonvehì J., Escura Pesudo F., Giner Pallares J. (1991) La détermination quantitative des acides aminés libres dans les pollens apicoles à l'aide de la chromatographie en phase gazeuse, chromatographie liquide haute performance et spectrophotométrie, Ann. Falsif. Expert. Chim. 84, 153-166.

Ummadi M., Weimer B.C. (2002) Use of capillary electrophoresis and laser-induced fluorescence for attomole detection of amino acids, J. Chromatogr. A 964, 243-253.

Woo K.L. (2001) Determination of Amino Acids in foods by Reversed-Phase High-Performance Liquid Chromatography in: Cooper C., Packer N., Williams K. (Eds.), Amino Acid Analysis Protocols, Humana Press, Totowa, NJ, p. 141. 